\title{
Anomali Desentralisasi Fiskal dan Kinerja Keuangan Daerah; Upaya Mengakselerasi Penerimaan Daerah Jurnal Ecces
}

\author{
Adya Utami Syukri ${ }^{1}$ \\ Program Studi Manajemen \\ STIE Tri Dharma Nusantara Makassar \\ Jl. Kumala II No. 51, Makassar, Sulawesi Selatan \\ E-mail : adya.utami@gmail.com
}

\section{Abstrak: Anomali Desentralisasi Fiskal dan Kinerja Keuangan Daerah; Upaya Mengakselerasi Penerimaan Daerah}

Pelaksanaan desentralisasi fiskal di Indonesia sejak tahun 2001 memaksa pemerintah daerah untuk berusaha keras dalam meningkatkan potensi dan penerimaan keuangan daerah, termasuk Provinsi Sulawesi Selatan sendiri. Namun, dibalik kebijakan desentralisasi fiskal ini, justru kinerja keuangan daerah Sulawesi Selatan belum begitu maksimal, sehingga penerimaan daerah ini terhitung masih rendah. Penelitian ini bertujuan untuk mengetahui bagaimana pengaruh desentralisasi fiskal dan kinerja keuangan daerah Provinsi Sulawesi Selatan. Penelitian ini menggunakan rumus menghitung derajat desentralisasi dan upaya fiskal. Data yang digunakan adalah data sekunder yaitu data dana perimbangan, pertumbuhan ekonomi, dan produk domestic regional bruto (PDRB) Provinsi Sulawesi Selatan periode 2008-2017. Hasil penelitian ini adalah Derajat Desentralisasi Fiskal Provinsi Sulawesi Selatan Periode 2008 - 2017 berada pada posisi $54.17 \%$ yang mengindikasikan bahwa Provinsi Sulawesi Selatan tidak terlalu bergantung kepada pemerintah pusat; Kapasitas Fiskal Provinsi Sulawesi Selatan cenderung fluktuatif selama periode 2008 - 2017; Tax Effort Provinsi Sulawesi Selatan secara rata - rata selama periode 2008 - 2017 berada pada posisi $0.82 \%$ yang menunjukkan bahwa penerimaan lebih kecil dari potensi pajak dan retribusi. Pemerintah Provinsi Sulawesi Selatan perlu mencari kombinasi yang tepat dalam peningkatan PAD dan BHPBP untuk mewujudkan kemandirian. Perlu adanya kreasi-kreasi yang dilakukan oleh Pemerintah Provinsi Sulawesi Selatan dalam meningkatkan penerimaan pajak dan retribusi

Kata Kunci: Desentralisasi fiskal ; Keuangan Daerah ; Penerimaan Daerah

\section{Abstract: Anomaly of Fiscal Decentralization and Financial Performance; Efforts to Accelerate Regional Revenue}

The implementation of fiscal decentralization in Indonesia since 2001 forced local governments to strive to increase the potential and regional financial revenues, including the 
province of South Sulawesi itself. However, behind this fiscal decentralization policy, the financial performance of the South Sulawesi region has not been maximized, so that the revenue of this region is calculated to be still low. This study aims to determine how the influence of fiscal decentralization and regional financial performance of South Sulawesi Province. This study uses a formula to calculate the degree of decentralization and fiscal efforts. The data used are secondary data, namely data on balance funds, economic growth, and gross regional domestic product (GRDP) of South Sulawesi Province for the period 2008-2017. The results of this study are the Degrees of Fiscal Decentralization in South Sulawesi Province for the period 2008 - 2017 at the position of $54.17 \%$ which indicates that the Province of South Sulawesi is not too dependent on the central government; Fiscal Capacity of South Sulawesi Province tends to fluctuate during the period 2008 - 2017; The South Sulawesi Province Tax Effort on average during the period of 2008 - 2017 is in the position of $0.82 \%$ which indicates that revenues are smaller than the potential of taxes and levies. The South Sulawesi Provincial Government needs to find the right combination in increasing PAD and BHPBP to realize independence. There needs to be creations made by the South Sulawesi Provincial Government in increasing tax revenues and retribution

Keywords: Fiscal decentralization; Regional Finance; Regional Revenue

\section{PENDAHULUAN / INTRODUCTION}

Pelaksanaan desentralisasi fiskal di Indonesia sejak tahun 2001 memaksa pemerintah daerah untuk berusaha keras dalam meningkatkan potensi dan penerimaan keuangan daerah, termasuk Provinsi Sulawesi Selatan sendiri. Namun, dibalik kebijakan desentralisasi fiskal ini, justru kinerja keuangan daerah daerah Sulawesi Selatan belum begitu maksimal, sehingga penerimaan daerah ini terhitung masih rendah. Situasi ini, tentunya tidak berbanding lurus dengan potensi ekonomi daerah Sulawesi Selatan yang begitu besar. Sebagai daerah otonom, pemerintah daerah Provinsi Sulawesi Selatan mempunyai wewenang dan tanggung jawab menyelenggarakan kepentingan masyarakat berdasarkan prinsip-prinsip keterbukaan, partisipasi masyarakat dan pertanggungjawaban kepada masyarakat. Prinsip dasar pemberian otonomi didasarkan atas pertimbangan bahwa daerahlah yang lebih mengetahui kebutuhan dan standar pelayanan bagi masyarakat di daerahnya. Atas dasar pertimbangan ini, maka pemberian otonomi diharapkan akan lebih mampu memacu pertumbuhan ekonomi dan kesejahteraan masyarakat pada akhirnya. 
Sebagaimana yang termuat dalam Undang-undang Otonomi daerah 2004:4 dan 220, desentralisasi dimaknai sebagai penyerahan wewenang pemerintah oleh pemerintah kepada daerah otonom untuk mengatur dan mengurus urusan pemerintah dalam sistem Negara Kesatuan Republik Indonesia.

Perwujudan desentralisasi fiskal yakni dengan adanya dana perimbangan. Ada perbedaan sudut pandang di dalam menyikapi masalah dana perimbangan ini. Di satu sisi, adanya dana perimbangan dalam otonomi daerah merupakan bentuk tanggung jawab dari pemerintah pusat atas berjalannya proses otonomi daerah. Hal ini juga sebagai wujud bahwa walaupun sistem yang diterapkan adalah sistem otonomi daerah, akan tetapi tetap dalam kerangka Negara Kesatuan Republik Indonesia. Namun di sisi yang lain, adanya dana perimbangan yang terlalu besar akan menimbulkan persepsi bahwa daerah tersebut tidak mandiri secara fiskal dan akan sampai pada kesimpulan akhir bahwa otonomi daerah tidak efektif untuk dilaksanakan. Pengalaman selama ini menunjukkan bahwa hampir di semua daerah prosentase Pendapatan Asli Daerah, relatif lebih kecil, sekitar 25\% dari total penerimaan daerah. Pada umumnya APBD (Anggaran Pendapatan dan Belanja Daerah) suatu daerah didominasi oleh sumbangan pemerintah pusat dan sumbangan-sumbangan lain, yang diatur dengan peraturan perundang-undangan, yaitu sekitar $75 \%$ dari total penerimaan daerah (Yani, 2002).

Pemerintah Provinsi Sulawesi Selatan juga turut melaksanakan prinsip desentralisasi fiskal seperti daerah - daerah lainnya di Indonesia. Pelaksanaan desentralisasi dimulai pada tahun 2001 dimana pada saat itu Provinsi Sulawesi Selatan dipimpin oleh Mayjen TNI (Purn.) H. Zainal Basri Palaguna (1994 - 2002), kemudian dilanjutkan oleh H.M. Amin Syam (2003 - 2008). Selanjutnya Provinsi Sulawesi Selatan dipimpin oleh DR. H. Syahrul Yasin Limpo, SH., MH. Bersama wakil gubernur Ir. H. Agus Arifin Nu'mang, MP. Pasangan gubernur dan wakil gubernur ini dikenal dengan sebutan "Sayang".

Di kepemimpinan "Sayang", Provinsi Sulawesi Selatan meraih prestasi nasional di bidang pemerintahan dan masuk salah satu dari enam provinsi terbaik dalam rangka Hari Otonomi Daerah XX Tahun 2016. Begitu pula di tahun 2015, Provinsi Sulawesi Selatan berhasil meraih predikat Wajar Tanpa Pengecualian (WTP) dalam laporan pengelolaan keuangan selama lima tahun berturut-turut. Untuk laporan pengelolaan keuangan tahun 2016 Provinsi Sulawesi Selatan pun meraih predikat WTP. 


\section{TINJAUAN TEORITIK / LITERATURE REVIEW}

\section{Desentralisasi}

Pembangunan daerah dapat dilakukan melalui dua pendekatan, yakni pendekatan sentralisasi dan pendekatan desentralisasi. Pendekatan sentralisasi mengandung arti bahwa pelaksanaan pembangunan sepenuhnya merupakan wewenang pusat dan dilaksanakan oleh para birokrat di pusat. Sedangkan pendekatan desentralisasi mengandung arti bahwa pembangunan daerah-melalui desentralisasi atau otonomi daerah-memberikan peluang dan kesempatan bagi terwujudnya pemerintahan yang bersih dan baik (good governance) di daerah. Artinya pelaksanaan tugas pemerintah daerah harus didasarkan atas prinsip efektif, efisien, partisipatif, terbuka (transparency), dan akuntabilitas (accountability).

Kebijakan dan tugas umum pemerintahan serta implementasi pembangunan di daerah di masa lampau merupakan wewenang dan tanggung jawab penuh dari pemerintah pusat, Jakarta. Kewenangan pemerintah pusat yang sangat besar tersebut ternyata tidak hanya berdampak positif bagi pembangunan, tetapi disadari juga menimbulkan efek negatif antara lain pertumbuhan ekonomi daerah atau produk domestik regional bruto (gross domestic regional product) yang relatif sangat lamban, serta panjangnya birokrasi pelayanan publik karena harus menunggu petunjuk dari para pejabat pusat. Hal ini menimbulkan keterlambatan pembangunan di daerah - daerah terutama bagi daerah - daerah yang jauh dari pemerintah pusat, Jakarta. Segala kebijakan yang diatur dan diputuskan oleh pemerintah pusat, termasuk keuangan daerah menyebabkan banyak kepentingan dan kebutuhan daerah yang tidak terakomodir. Pemerintah pusat mengambil kebijakan dari sudut pandang mereka bukan dari sudut pandang daerah. Sementara yang mengetahui kebutuhan daerah adalah daerah itu sendiri bukan pemerintah pusat.

Beranjak dari permasalahan yang timbul di masa pemerintahan sentralistik maka pemerintah merumuskan undang - undang mengenai otonomi daerah. Indonesia memasuki era otonomi daerah sejak tanggal 1 Januari 2000. Pelaksanaan otonomi daerah mengacu pada UU nomor 32 tahun 2004 mengenai pembagian kewenangan dan fungsi (power sharing) antara pemerintah pusat dan daerah dan UU nomor 33 tahun 2004 mengenai perimbangan keuangan pusat dan daerah yaitu pengaturan pembagian sumber-sumber 
daya keuangan (financial sharing) antara pusat-daerah sebagai konsekuensi dari adanya pembagian kewenangan tersebut.

Pengalihan pembiayaan atau desentralisasi fiskal secara singkat dapat diartikan sebagai suatu proses distribusi anggaran dari tingkat pemerintahan yang lebih tinggi kepada pemerintahan yang lebih rendah, untuk mendukung fungsi atau tugas pemerintahan dan pelayanan publik sesuai dengan banyaknya kewenangan bidang pemerintahan yang dilimpahkan (Saragih, 2003: 83). Prinsip dasar pelaksanaan desentralisasi fiskal di Indonesia ialah "Money Follows Functions", yaitu fungsi pokok pelayanan publik didaerahkan, dengan dukungan pembiayaan pusat melalui penyerahan sumber-sumber penerimaan kepada daerah. Prinsip tersebut berarti setiap penyerahan atau pelimpahan wewenang pemerintahan membawa konsekuensi pada anggaran yang diperlukan untuk melaksanakan kewenangan tersebut (Ibid : 83).

Dalam pandangan Oates (1993) dan Bahl (2000) secara sederhana kemandirian fiskal berarti bahwa pemerintah dapat membiayai semua pengeluaran dengan penerimaannya sendiri tanpa bergantung pada transfer dan pinjaman. Pengertian kedua yang secara struktural sama dengan yang pertama namun berbeda substansinya, yaitu bahwa pemerintah dapat menutup pengeluaran operasionalnya dengan penerimaan rutinnya diluar transfer. Pengertian ketiga mencakup semua pengeluaran (termasuk investasi) dengan dana dari penerimaan sendiri, transfer dan pinjaman. Desentralisasi fiskal akan mampu meningkatkan pertumbuhan ekonomi dan kesejahteraan masyarakat, karena pemerintah sub nasional/pemerintah daerah akan lebih efisien dalam produksi dan penyediaan barang-barang publik. Pengambilan keputusan pada level pemerintah lokal akan lebih didengarkan untuk menganekaragamkan pilihan lokal dan lebih berguna bagi efisensi alokasi. Desentralisasi fiskal di negara-negara berkembang apabila tidak berpegang pada standar teori desentralisasi, hasilnya mungkin akan merugikan pertumbuhan ekonomi dan efisiensi. Desentralisasi fiskal memungkinkan untuk melakukan korupsi pada level lokal karena memberikan pertimbangan politikus lokal. Dalam perkembangannya, paradigma pembangunan ekonomi ternyata tidak begitu mudah diterapkan di negara-negara berkembang yang memiliki karakter dan kebudayaannya sendiri. Implementasi paradigma ini membutuhkan investasi yang besar guna memacu pertumbuhan, sementara modal yang dimiliki negara berkembang secara umum relatif terbatas. Konsekuensinya modal tersebut akan dipusatkan pada sektor-sektor tertentu yang menjadi prioritas dan pemusatan ini 
membutuhan mekanisme pengendalian yang kuat sehingga terjadi sentralisasi kebijakan pembangunan. Dampak jangka panjang dari pemusatan pembangunan ini adalah ketidakmerataan sumber daya antar daerah yang tidak dapat diperbaiki dalam jangka pendek.

Desentralisasi harus memacu adanya persaingan di antara berbagai pemerintah lokal untuk menjadi pemenang (there must be a champion for fiscal decentralization). Hal ini dapat dilihat dari semakin baiknya pelayanan publik. Pemerintah lokal berlomba-lomba untuk memahami benar dan memberikan apa yang terbaik yang dibutuhkan oleh masyarakatnya, perubahan struktur ekonomi masyarakat dengan peran masyarakat yang semakin besar meningkatkan kesejahteraan rakyat, partisipasi rakyat setempat dalam pemerintahan dan lain-lain. Desentralisasi fiskal memang tidak secara jelas dinyatakan dalam UU Nomor 33 Tahun 2004. Namun, komponen dana perimbangan merupakan sumber penerimaan daerah yang sangat penting dalam pelaksanaan desentralisasi. Dalam kebijakan fiskal, dana perimbangan merupakan inti dari desentralisasi fiskal. Secara historis, desentralisasi di Indonesia sebenarnya sudah dikenal jauh sebelum kemerdekaan. Pada masa pemerintah kolonial Belanda telah dikenal sistem desentralisasi untuk memenuhi tuntutan kalangan orang-orang Eropa, Timur Asing dan kalangan elit Indonesia yang memandang pemerintah kolonial terlalu sentralitis. Gubernur Jenderal dan jajaran menteri jajahannya selaku pemerintah pusat saat itu mengakui adanya daerah-daerah otonom seperti desa, nagari, kuria, marga dan sebagainya. Dalam administrasinya dikenal adanya tiga tingkatan pemerintahan yaitu provinsi, regentschap dan stadsgemeente.

Ada beberapa tinjauan tentang desentralisasi fiskal. Rumah tangga dalam memilih barang publik bebas bergerak dari satu pemerintahan ke pemerintahan lainnya dengan mempertimbangkan barang publik dan pajak daerah yang dapat memaksimumkan kesejahteraan pemilih "voting with feet". Dengan kebijakan desentralisasi fiskal ini, pelayanan yang diberikan pemerintah akan lebih sesuai dengan permintaan masyarakat setempat sehingga kepercayaan masyarakat pada pemerintah akan meningkat. Dengan demikian diharapkan masyarakat akan lebih rela membayar jasa layanan mengingat pilihannya diperhatikan pemerintah. Ini berarti desentralisasi akan meningkatkan mobilisasi dana dari masyarakat. Selanjutnya, diidentifikasi empat dimensi sebagai pilar desentralisasi 
fiskal. Pertama, pemberian tanggung jawab pengeluaran yang didasarkan kemampuan tiap tingkat pemerintah dalam penyediaan barang dan jasa secara efisien. Yang kedua penentuan sumber-sumber penerimaan yang didasarkan pada prinsip finance should follow function. Yang ketiga, transfer keuangan antar tingkat pemerintahan guna menjamin kecukupan dana untuk melaksanakan fungsi pengeluaran. Keempat, pinjaman daerah bila pemerintah daerah dimungkinkan untuk melaksanakan pembelanjaan defisit. Desentralisasi fiskal sebagai perubahan pola pengelolaan keuangan yang menyangkut masalah financing reform dan budgetting reform. Financing reform berkenaan dengan perubahan sumbersumber penerimaan daerah, sedangkan budgetting reform berkaitan dengan perubahan pengaturan alokasi pengeluaran. Oleh karena itu pembahasan desentralisasi fiskal akan selalu berpangkal dari telaah penerimaan dan pengeluaran daerah dan berujung pada pencapaian kemandirian dan pemerataan dalam pemberian pelayanan umum kepada masyarakat.

Desentralisasi itu sendiri karena pemberian kewenangan di bidang politik maupun administrasi tanpa dibarengi dengan desentralisasi fiskal merupakan desen-tralisasi yang sia-sia, sebab untuk dapat melaksanakan kewenangan dan tanggung jawab serta tugastugas pelayanan publik tanpa diberi wewenang di dalam penerimaan maupun pengeluaran desentralisasi fiskal tidak akan efektif. Dengan demikian, desen-tralisasi fiskal akan memberi keleluasaan kepada daerah untuk menggali potensi daerah dan memperoleh transfer dari pusat dalam kerangka keseimbangan fiskal. Terdapat beberapa alasan untuk mempunyai sistem pemerintahan yang terdesentralisai (Simanjuntak, 2001): (1) Representasi demokrasi, umtuk memastikan hak seluruh warga negara untuk berpartisipasi secara langsung pada keputusan yang akan mem-pengaruhi daerah atau wilayah (2) Tidak dapat dipraktekkannya pembuatan kepu-tusan yang tersentralisasi, adalah tidak realistis pada pemerintahan yang sentralistis untuk membuat keputusan mengenai semua pelayanan rakyat seluruh negara, terutama pada negara yang berpenduduk besar seperti Indonesia (3) Pengetahuan lokal (lokal knowledge), mereka yang berada pada daerah lokal mempunyai pengetahuan yang lebih banyak mengenai kebutuhan lokal, prioritas, kondisi, dll (4) Mobilitas sumber daya, mobilitas pada bantuan dan sumber daya dapat di fasilitasi dengan hubungan yang lebih erat di antara populasi dan pem-buat kebijakan pada tingkat lokal.

Reformasi administrasi dan manajemen di berbagai negara yang berkembang sejak tahun 1980an berkaitan dengan peran negara terhadap pemenuhan kebutuhan warganya 
(citizens). Kebutuhan jangka pendek ataupun jangka panjang, reformasi sangat diperlukan berkaitan dengan enam karakteristik inti (six core characteristics). Pertama, produktivitas (productivity) dalam arti bagaimana pemerintah menyediakan layanan yang diperlukan warga dengan pajak/biaya yang murah kendati pemerintah memerlukan peningkatan sumber pendapatan. Kedua, berlakunya mekanisme pasar (marketization) dalam arti bagaimana pemerintah dapat memberi peluang berperannya mekanisme pasar untuk mengurangi terjadinya patologi birokrasi melalui strategi perubahan perilaku di tingkat manajerial. Ketiga, orientasi pelayanan (service orientation) dalam arti bagaimana pemerintah membangun jaringan dengan warga dalam penyediaan layanan melalui berbagai mekanisme alternatif pilihan, termasuk pilihan penggunaan mekanisme pasar. Keempat, desentralisasi (decentralization) dalam arti bagaimana pemerintahan merancang programprogram yang responsif, efektif dan efesien melalui kebijakan desentralisasi politik dan desentralisasi administrasi. Kelima, kebijakan (policy) dalam arti bagaimana pemerintah membangun kapasitas institusi melalui berbagai kebijakan di tingkat manajerial ataupun di tingkat operasional. Keenam, pertanggungjawaban hasil yang dicapai (accountability for results) dalam arti bagaimana pemerintah mewujudkan pertanggungjawaban melalui mekanisme top down dan bottom up yang berorientasi pada hasil dan dampak kebijakan untuk kepentingan warga.

Namun berbeda dengan pandangan Marx dalam Thayer (2016), Brown (2009), Nappalos (2013) melihat alokasi fiskal, yang cenderung bersifat sentralistik. Sentralisme dianggap penting untuk menciptakan keadilan distribusi pendapatan yang lebih baik dan berkeadilan, untuk kesejahteraan masyarakat dan mengatasi adanya ketimpangan ekonomi yang terjadi. Analisis sentralisme tersebut, memiliki tinjauan teoritik dan historis yang begitu panjang. Pendekatan sentralisme tersebut, mengacu pada analisis strukturalis Marxis memiliki pijakan teoretis mengenai fenomena patronase. Sebab jika dilihat dari berbagai literatur strukturalis Marxis maka tampak terlalu berfokus pada kebijakan-kebijakan institusional dan kerap abai terhadap fenomena berbasis kultur seperti patronase. Prinsip sentralisme demokratik sama seperti sentralisme birokratik. Sebagai salah satu fitur institusional penting yang dimiliki oleh negara komunis, sentralisme demokratik sejatinya mengakui keberadaan nilai-nilai partikularitas. Namun demikian dalam perjalanannya, 
prinsip yang pertama kali dicetuskan oleh Bastian von Schweitzer tersebut, sering kali dimaknai di dalam diskusi-diskusi secara peyoratif menjadi 'sentralisme birokratik' akibat tafsir Lenin ketika mendalangi Partai Buruh Sosial Demokrat Rusia (RSDV) - menjadi: konsep pemerintahan pabrik dibawah kepemimpinan seseorang yang melakukan militerisasi terhadap buruh. Jika dilihat dari penelusuran historis yang dilakukan, Lenin jelas bukanlah satu-satunya orang yang mengembangkan sentralisme demokratik.

Banyak tokoh lain, seperti Bordiga (1926) yang menafsirkannya kemudian menjadi sentralisme organik, atau Gramsci yang pemikirannya dijadikan rujukan dalam tulisan ini. Semisal dengan mengutip kalimatnya Gramsci di tahun 1971 bahwa sentralisme demokratik menawarkan formula yang elastis. Ia dapat hidup selama diinterpretasi dan diadaptasikan sesuai dengan kebutuhan. Ia memiliki dorongan untuk mengejar apa yang identic dalam keberagaman, dan di sisi lain, mencari apa yang berbeda hingga bahkan bertentangan dalam kesatuan, dalam rangka mengorganisasi dan menghubungkan secara erat apa yang mirip, tetapi dalam hal pengorganisan, ia muncul secara praktikal dan induktif berdasarkan kebutuhan, dan bukan sebagai hasil proses abstraksi rasional, deduktif seperti yang dicontohkan oleh seorang intelektual.

Kita mungkin akan memahami bahwa menurut Gramsci, sentralisme demokratik tidaklah sama dengan tafsiran Lenin atau Bordiga. Jika Lenin dan Bordiga sama-sama menganggap sentralisme demokratik sebagai prinsip yang monolitik-birokratis, Gramsci justru memahaminya sebagai prinsip yang mesti mengakui pandangan plural dari seluruh unit yang diwakilinya. Maka jika logika berpikir Gramsci tersebut digunakan, kiranya dapat diduga bahwa penjelasan mengenai fenomena kebertahanan sebuah rezim komunis akan terlihat menjadi lebih realistis, sebab partai tidak perlu menciptakan institusi kepartaian yang sama persis dan terkontrol dari pusat hingga pelosok desa. Selain karena memiliki biaya sosial yang terlalu mahal, keberadaannya juga niscaya tidak akan pernah mampu menghasilkan kemampuan beradaptasi partai yang baik dalam menghadapi beragam dinamika politik - semisal rivalitas antarelite - yang sudah pasti akan terjadi.

Menurut Dilliger dalam Sidik (2002), Slack dan Bird (2004), berpendapat bahwa pada dasarnya terdapat empat jenis desentralisasi, yaitu: Desentralisasi politik (political decentralization), yaitu pemberian hak kepada warga Negara melalui per-wakilan yang dipilih suatu kekuasaan yang kuat untuk mengambil keputusan publik, desentralisasi administrative (administrative decentralization), yaitu pelimpahan wewenang guna 
mendistribusikan wewenang, tanggung jawab dan sumber-sumber ke-uangan untuk menyediakan pelayanan public, terutama yang menyangkut peren-canaan, pendanaan dan manajemen fungsi-fungsi pemerintahan dari pemerintah pusat kepada aparat di daerah, badan otoritas ter-tentu atau perusahaan tertentu, Desentralisasi fiskal (fiscal dezentralization) yaitu pelimpahan wewenang dalam mengelola sumber-sumber keuangan, yang mencakup: a) Self-financing atau cost recorvery dalam pelayanan publik terutama melalui pengenaan retribusi daerah b) Cofinancing atau coproduction, di mana pengguna jasa berpartisipasi dalam bentuk pembayaran jasa atau kontribusi tenaga kerja c) Transfer dari pemerintah pusat terutama berasal dari Dana Alokasi Umum (DAU), Dana Alokasi Khusus (DAK), sumbangan darurat, serta pinjaman daerah (sumber daya alam) dan Desentralisasi ekonomi (economic or market decentralization), yaitu kebijakan tentang privatisasi dan deregulasi yang intinya berhubungan dengan kebijakan pelimpahan fungsifungsi pelayanan masyarakat dari pemerintah kepada sektor swasta sejalan dengan kebijakan liberalisasi.

Desentralisasi fiskal membawa konsekuensi bagi pemerintah daerah untuk mandiri baik dalam sistem pembiayaan maupun dalam menentukan arah pengeluarannya sesuai dengan prioritas dan kepentingan masyarakat di daerah. Dengan demikian daerah mampu membiayai kebutuhan pengeluarannya dengan kapasitas fiskal yang dimiliki sehingga terjamin adanya keberlanjutan fiskal (fiskal sustainability). Kemandirian fiskal merupakan konsep yang enak didengar namun belum memiliki batasan yang jelas apa pengertian yang sebenarnya. Kemandirian seperti halnya konsep anggaran berimbang lebih dekat sebagai art daripada science.

Dalam hal ini, arti dan maksud dari kemandirian sangat tergantung kepentingan dan siapa yang menggunakan dan pengukurannya pun sangat tergantung ketersediaan data. Indikator yang digunakan dalam penelitian di beberapa negara mengenai tingkat kemandirian fiskal lebih banyak didasarkan pada analisis strukur penerimaan dan pengeluaran pemerintah daerah. Walaupun diakui bahwa kontribusi penerimaan pemerintah daerah terhadap total penerimaan dan pengeluaran maupun GDP bukan suatu ukuran yang memadai, namun sampai saat ini masih sebatas data itulah yang bisa diperoleh. Oleh 
Adya Utami Syukri, Anomali Desentralisasi Fiskal ...

karena itu, perbandingan desentralisasi fiskal antar negara masilh sulit dilakukan baik karena kesulitan agregasi data maupun perbedaan pemahaman desentralisasi sektor publik.

\section{METODE PENELITIAN / METHODS}

Derajat desentralisasi fiskal adalah tingkat kemandirian daerah untuk membiayai kebutuhan daerahnya sendiri tanpa menggantungkan diri dengan pemerintah pusat. Kemandirian fiskal pemerintah daerah di Indonesia dapat dilihat dari besarnya kontribusi PAD dan dana bagi hasil terhadap total penerimaan daerah.

Derajat desentralisasi fiskal dapat dihitung dengan cara:

Rumus 1:

$$
D D F=\frac{\text { Pendapatan Asli Daerah }}{\text { Total Pendapatan Daerah }}
$$

Rumus 2:

$$
D D F=\frac{\text { Bagi Hasil Pajak dan Bukan Pajak }(\text { BHPBP })}{\text { Total Pendapatan Daerah }}
$$

Rumus 3:

$$
D D F=\frac{\text { Dana Perimbangan }(D P)}{\text { Total Pendapatan Daerah }(T P D)}
$$

1. Kapasitas Fiskal

Kapasitas fiskal daerah dapat didefinisikan sebagai kemampuan potensial pemerintah daerah untuk meningkatkan penerimaan yang berasal dari pendapatan asli daerahnya untuk membiayai standarisasi penyediaan barang dan jasa publik.

Kapasitas fiskal daerah merupakan sumber pendanaan daerah yang berasal dari PAD dan dana bagi hasil.

Kapasitas fiskal dapat dihitung dengan formula:

$$
F C=P A D+B H P B P
$$

Untuk mengetahui prosentase pertumbuhan kapasitas fiskal dapat dihitung dengan formula:

$$
F C(\%)=\Delta F C \times 100 \%
$$


2. Upaya Fiskal

Upaya fiskal (Tax Effort) dapat didefinisikan sebagai rasio antara total penerimaan pajak/ retribusi dengan kapasitas fiskal suatu propinsi, kabupaten/kota.

Secara sederhana dapat ditulis sebagai berikut:

Upaya Fiskal daerah dapat dihitung dengan formula:

$$
\text { Tax Effort }(T E)=\frac{\text { Total tax collection }(T C)}{\text { Fiscal capacity }(F C)}
$$

Terdapat tiga alternatif hasil TE yang bisa terjadi yaitu masing-masing $\mathrm{TE}=1$; $\mathrm{TE}<$ 1; dan TE > 1. Pertama, bilamana hasil perhitungan menunjukkan bahwa TE $=1$, ini berarti bahwa penerimaan sesuai dengan kapasitas/potensi pajak dan retribusi yang ada. Bilamana perhitungan kapasitas adalah akurat maka, TE $=1$ menunjukkan pengelolaan pengumpulan pajak dan retribusi adalah efektif. Kedua, bilamana $\mathrm{TE}<1$, artinya penerimaan lebih kecil dari potensi kapasitas pajak dan retribusi. Jika terjadi demikian maka terdapat masalah pada manajemen pengumpulan pajak dan retribusi. Sejumlah kemungkinan penyebab antara lain adanya penghindaran pajak (tax aversion) oleh wajib pajak; adanya moral hazar yang dilakukan oleh pengumpul dan lain-lain. Dan ketiga, bilamana TE $>1$, artinya penerimaan lebih besar dari potensi pajak dan retribusi. Jika terjadi demikian maka hasil estimasi atas kapasitas fiskal dibawah potensi yang sesungguhnya (under estimate). Hal ini juga mengandung pengertian bahwa masih ada potensi penerimaan dari sumber-sumber pajak dan retribusi yang belum teridentifikasi pada proses estimasi potensi kapasitas fiskal yang dilakukan.

\section{HASIL DAN PEMBAHASAN / DISCUSSION}

\section{Derajat Desentralisasi Fiskal}

Berdasarkan APBD Provinsi Sulawesi Selatan dalam kurun waktu 2008-2017 dapat dilihat besaran PAD dan hubungannya dengan total penerimaan daerah pada tabel yang ada. Dari perhitungan Tabel 1, terlihat bahwa secara rata-rata dalam kurun waktu 10 tahun (2008-2017) proporsi PAD terhadap TPD sekitar 54.17\%. hal ini menunjukkan bahwa Provinsi Sulawesi Selatan tidak terlalu bergantung dengan pemerintah pusat. Provinsi 
Sulawesi Selatan mulai bisa membiayai kebutuhannya walaupun masih membutuhkan sokongan dari pemerintah pusat. Hal ini perlu menjadi salah satu perhatian bagi Gubernur selanjutnya untuk terus meningkatkan DDF Provinsi Sulawesi Selatan sehingga tidak bergantung terhadap pemerintah pusat mengingat bahwa Provinsi Sulawesi Selatan adalah salah satu provinsi di Indonesia yang memiliki kekayaan alam yang melimpah.

Tabel 1. Derajat Desentralisasi Fiskal Provinsi Sulawesi Selatan periode 2008-2017.

\begin{tabular}{cccc}
\hline \multirow{2}{*}{ Tahun } & PAD & TPD & Derajat Desentralisasi \\
\cline { 2 - 4 } & (Rp 000) & (Rp 000) & (\%) \\
\hline 2008 & $1,128,383,621.00$ & $2,133,624,782.00$ & 52.89 \\
\hline 2009 & $1,242,838,310.00$ & $2,209,465,000.00$ & 69.25 \\
\hline 2010 & $1,782,147,365.00$ & $2,564,075,935.00$ & 63.00 \\
\hline 2011 & $1,959,515,902.00$ & $3,110,566,841.00$ & 49.59 \\
\hline 2012 & $2,198,776,396.00$ & $4,433,963,020.00$ & 52.59 \\
\hline 2013 & $2,560,045,632.00$ & $4,867,592,610.00$ & 55.54 \\
\hline 2014 & $3,107,044,871.00$ & $5,593,932,515.00$ & 53.57 \\
\hline 2015 & $3,270,905,972.00$ & $6,105,892,555.00$ & 48.16 \\
\hline 2016 & $3,449,561,308.00$ & $7,162,588,691.00$ & 40.63 \\
\hline 2017 & $3,679,083,943.00$ & $9,055,278,907.00$ & \\
\hline
\end{tabular}

Sumber: Data Diolah, 2019

Beberapa Kabupaten di Provinsi Sulawesi Selatan sudah mulai membangun kerja sama dengan Negara lain. Misalnya saja Kab.Bantaeng dan Kab. Pinrang yang memperoleh bantuan dari pemerintah Jepang. Selain itu pemerintah Provinsi sendiri berusaha untuk menarik investor agar mau berinvestasi di Sulawesi Selatan, misalnya investor dari Filipina dan Malaysia di sector kehutanan. Hal ini menunjukkan keinginan pemerintah daerah untuk tidak terlalu bergantung dengan transfer fiscal pemerintah pusat.

Penerimaan daerah tidak terlepas dari Dana Perimbangan (DP). DP terdiri dari Dana Alokasi Umum (DAU), Dana Alokasi Khusus (DAK), dan Dana Bagi Hasil Pajak dan Non Pajak. Dana Alokasi Umum (DAU) masih menjadi primadona dalam transfer fiscal pemerintah pusat hingga mencapai $\pm R p 15 M$ di tahun 2014. Hal ini disebabkan sebagian 
besar peruntukan DAU adalah untuk membiayai gaji pegawai negeri sipil (PNS) di lingkup pemerintah daerah, tentunya semakin banyak jumlah PNS di daerah tersebut maka semakin banyak pula DAU yang digunakan. DAU bersifat general dalam penggunaannya dimana daerah dapat menggunakan dana tersebut sesuai dengan kebutuhan daerah itu sendiri. DAU adalah dana transfer ke daerah yang bersifat pasti dimana besarannya berdasarkan formulasi DAU yang telah ditetapkan pemerintah. Berbeda halnya dengan DAK yang bersifat specific dimana penggunaan DAK untuk masing-masing daerah telah diatur oleh pemerintah pusat. Sehingga DAK lebih banyak digunakan untuk infrastruktur, pariwisata, dan lain-lain. Tidak semua daerah di Indonesia mendapatkan DAK setiap tahunnya. Hal ini disebabkan penyaluran DAK diarahkan kepada daerah yang dianggap tertinggal dalam hal pelayanan publik agar seluruh rakyat Indonesia dapat menikmati fasilitas publik sesuai dengan Standar Pelayanan Minimum (SPM) sehingga dapat meningkatkan kesejahteraan daerah. Sementara DBH baik Pajak maupun Bukan Pajak diberikan berdasarkan porsi pajak dan sumber daya alam (SDA) yang dimiliki oleh daerah itu sendiri. Pertentangan sering muncul pada daerahdaerah yang memiliki SDA yang melimpah seperti Kalimantan timur, Papua, dan Papua Barat. Daerah-daerah ini menganggap pembagian DBH-BP tidak merata, karena mereka menganggap bagi hasil untuk daerah penghasil masih sangat kurang sementara pajak yang mereka hasilkan sangatlah besar. Pertentangan juga terjadi pada pembagian DAU dimana formulasi DAU yang selama ini digunakan dianggap kurang tepat untuk masing-masing daerah. Oleh karena itu pemerintah pusat masih berupaya untuk mereformulasi formula DAU agar pembagiannya dapat seimbang.

\section{Kapasitas Fiskal}

Berdasarkan gambar yang terlihat bahwa kapasitas fiskal provinsi Sulawesi Selatan berfluktuatif selama periode 2008-2017. Berdasarkan teori, semakin tinggi hasil perhitungan kapasitas fiskal suatu daerah, maka dikatakan semakin baik. Artinya kemampuan daerah tersebut untuk menghasilkan barang atau jasa semakin produktif. Berdasarkan data yang diperoleh, kondisi fluktuatif ini terjadi akibat peningkatan PAD yang tidak sebanding dengan peningkatan BHPBP, bahkan di tahun 2015 PAD Provinsi Sulawesi Selatan meningkat menjadi Rp 3,270,905,972,000 namun BHPBP menurun menjadi Rp 188,057,830,000. 
Kapasitas fiskal Provinsi Sulawesi Selatan periode 2008-2017 merupakan penjumlahan dari PAD dan BHPBP yang dapat dilihat pada table dibawah ini:

Gambar 1 . Kapasitas Fiskal Provinsi Sulawesi Selatan periode 2008-2017

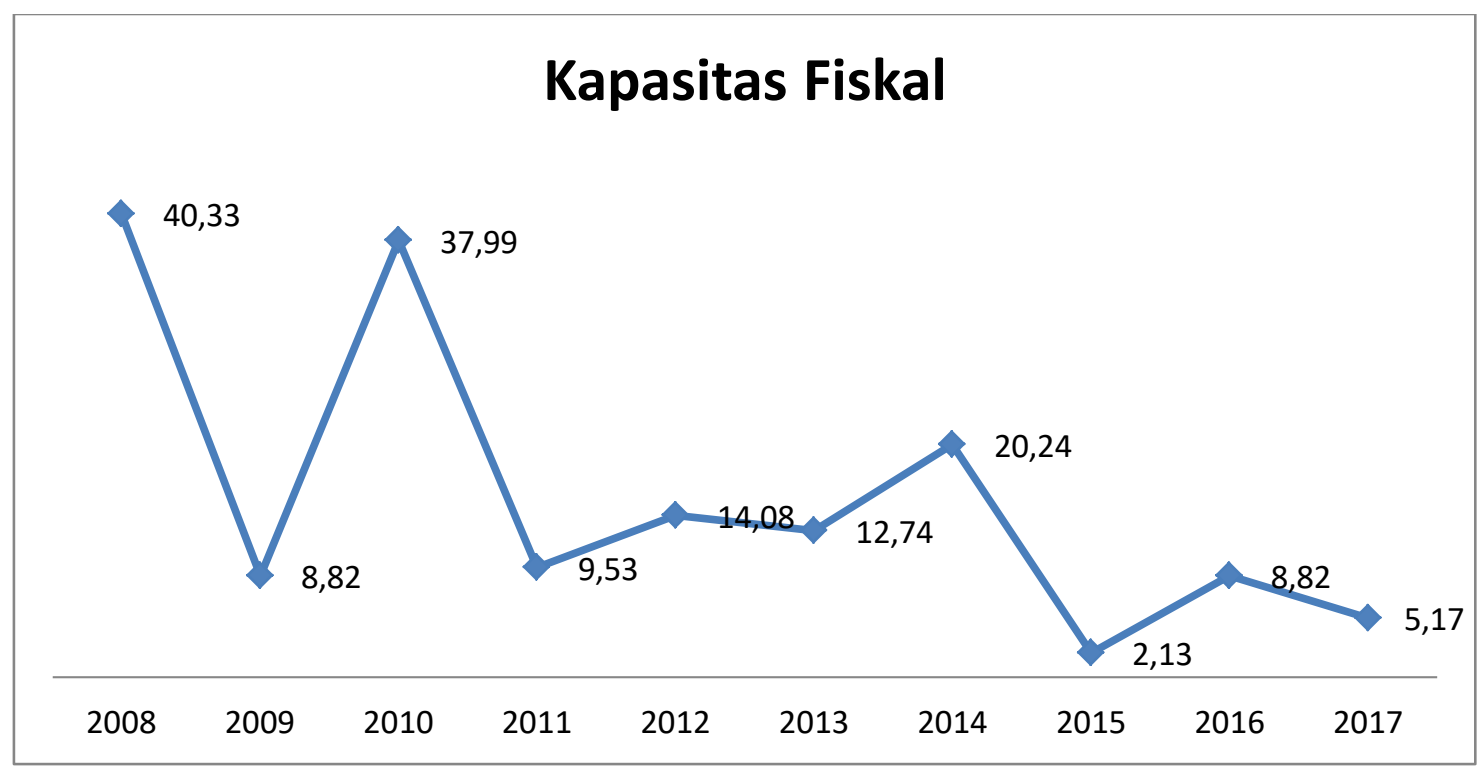

Sumber: Data Diolah, 2019

Hasil fluktuatif yang cenderung menurun menunjukkan bahwa dari sisi produksi barang dan jasa di Provinsi Sulawesi Selatan masih perlu ditingkatkan. Provinsi Sulawesi Selatan bukan hanya sebagai distributor barang dan jasa dari Indonesia bagian Barat ke Indonesia bagian timur, tapi bagaimana caranya Provinsi Sulawesi Selatan juga sebagai produsen barang dan jasa. Tentu saja dengan pemanfaatan sumber-sumber daya yang ada di Provinsi Sulawesi Selatan. Provinsi Sulawesi Selatan memiliki banyak sekali sumber daya, baik itu sumber daya alam, sumber daya manusia, dan sumber daya alam. Pemerintah perlu menyusun strategi untuk memanfaatkan sumber daya yang ada secara efektif dan efisien.

Beberapa kabupaten di Provinsi Sulawesi Selatan memiliki kekayaan alam yang berlimpah. Pemerintah Provinsi Sulawesi Selatan perlu bekerja sama dengan pemerintah daerah untuk memanfaatkan sumber daya yang dimiliki oleh kabupaten tersebut. Misalnya Kabupaten Luwu Timur dan Pangkep yang memiliki daerah pertambangan tentunya memiliki PDRB yang cukup tinggi sehingga dapat memajukan daerah itu sendiri. Kota Makassar walaupun tidak memiliki areal pertanian yang banyak, tapi dapat tumbuh dengan banyaknya industry-industri jasa yang berada di Kota Makassar. Ketiga daerah ini adalah daerah-daerah yang memiliki PDRB per kapita 2014 cukup tinggi dibanding daerah-daerah lain yakni 
berturut-turut $\pm R p 75 j u t a, \pm R p 49 j u t a$, dan $\pm R p 69 j u t a$. Sementara daerah-daerah miskin seperti Kab. Jeneponto ( \pm Rp17juta) dan Kab. Gowa ( \pm Rp16juta) perlu berusaha lebih keras untuk meningkatkan pendapatannya untuk mengejar ketertinggalan dengan daerah lain. Selama 5 tahun terakhir, PDRB per kapita Kab/Kota di Sulawesi Selatan mengalami peningkatan namun ada daerah yang meningkat dengan pesat, ada juga yang peningkatannya lambat. Daerah yang cukup pesat pertumbuhannya adalah Kab. Selayar dan Kab. Bantaeng. Kedua kabupaten ini dipandang sebagai kabupaten yang cukup terbelakang di Sulawesi Selatan. Namun dengan kerja keras dari seluruh stakeholder di Kabupaten tersebut, mereka dapat tumbuh dengan baik. Tercatat bahwa PDRB per kapita Kab. Selayar di tahun $2010 \pm$ Rp14juta meningkat menjadi \pm Rp26juta di tahun 2014. Sementara Kab. Bantaeng di tahun $2010 \pm$ Rp15juta menjadi \pm Rp27juta di tahun 2014.

3. Tax Effort

Tabel 2. Tax Effort Provinsi Sulawesi Selatan Periode 2008 - 2017

\begin{tabular}{rccc}
\hline \multirow{2}{*}{ Tahun } & Total Pajak & Kapasitas Fiskal & Tax Effort \\
\cline { 2 - 4 } & Rp 000 & & \\
\hline 2008 & $1,141,138,028.00$ & $1,331,609,571.00$ & 0.86 \\
\hline 2009 & $1,145,535,913.00$ & $1,449,069,750.00$ & 0.79 \\
\hline 2010 & $1,443,364,897.00$ & $1,999,533,278.00$ & 0.72 \\
\hline 2011 & $1,840,817,438.00$ & $2,190,122,507.00$ & 0.84 \\
\hline 2012 & $2,062,252,806.00$ & $2,498,456,973.00$ & 0.83 \\
\hline 2013 & $2,313,956,603.00$ & $2,816,857,781.00$ & 0.82 \\
\hline 2014 & $2,761,862,378.00$ & $3,386,936,854.00$ & 0.82 \\
\hline 2015 & $2,996,560,017.00$ & $3,458,963,802.00$ & 0.87 \\
\hline 2016 & $3,166,194,937.00$ & $3,763,904,830.00$ & 0.84 \\
\hline 2017 & $3,323,998,232.00$ & $3,958,610,873.00$ & 0.84 \\
\hline
\end{tabular}

Sumber: Data Diolah, 2019

Kemampuan pajak atau Tax Effort Provinsi Sulawesi Selatan periode 2008 - 2017 rata - rata sebesar 0.82. Angka ini menunjukkan bahwa penerimaan lebih kecil dari potensi kapasitas pajak dan retribusi. Jika terjadi demikian maka terdapat masalah pada manajemen pengumpulan pajak dan retribusi. Sejumlah kemungkinan penyebab antara lain adanya 
penghindaran pajak (tax aversion) oleh wajib pajak; adanya moral hazar yang dilakukan oleh pengumpul dan lain-lain.

Beberapa upaya yang perlu dilakukan dalam pengelolaan pajak antara lain:

1. Pengawasan langsung objek-objek pajak

2. Penyuluhan kepada masyarakat dan wajib pajak mengenai pentingnya pajak

3. Meningkatkan pelayanan perpajakan kepada masyarakat yang membayar pajak dan penyederhanaan prosedur dan administrasi pengelolaan pajak daerah

4. Melakukan penyempurnaan atau perubahan terhadap peraturan daerah yang tidaksesuai lagi.

Meningkatkan pengawasan dan pengendalian pengelolaan keuangan daerah terhadap penyimpangan prosedur sesuai dengan ketentuan yang dapat merugikan pemerintahan daerah, baik secara yuridis, teknis maupun penatausahaan

\section{KESIMPULAN / CONCLUSION}

Derajat Desentralisasi Fiskal Provinsi Sulawesi Selatan Periode 2008 - 2017 berada pada posisi $54.17 \%$ yang mengindikasikan bahwa Provinsi Sulawesi Selatan tidak terlalu bergantung kepada pemerintah pusat. Kapasitas Fiskal Provinsi Sulawesi Selatan cenderung fluktuatif selama periode 2008 - 2017. Tax Effort Provinsi Sulawesi Selatan secara rata rata selama periode 2008 - 2017 berada pada posisi $0.82 \%$ yang menunjukkan bahwa penerimaan lebih kecil dari potensi pajak dan retribusi. Pemerintah Provinsi Sulawesi Selatan perlu mencari kombinasi yang tepat dalam peningkatan PAD dan BHPBP untuk mewujudkan kemandirian. Perlu adanya kreasi-kreasi yang dilakukan oleh Pemerintah Provinsi Sulawesi Selatan dalam meningkatkan penerimaan pajak dan retribusi. Bagi peneliti selanjutnya, dapat menambahkan analisis mengenai kebutuhan fiskal yang belum termuat dalam tulisan ini.

\section{DAFTAR PUSTAKA / REFERENCES}

Badan Pusat Statistik, Provinsi Sulawesi Selatan dalam Angka, berbagai edisi. Sulawesi Selatan.

Bahl, Roy W., 2000. China: Evaluating the Impact of Intergovernmental Fiscal Reform dalam Fiscal Decentralization in Developing Countries. Edited by Richard M. Bird and Francois Vaillancourt, United Kingdom: Cambridge University Press. 
Bird, Richard M., 1990. Intergovernmental Finance and Local Taxation in Developing Countries Some Basic Consideration for Reformers. Public Administration and Development

Brown, Archie. 2009. The Rise and Fall of Communism. New York: HarperCollins.

Brojonegoro, Bambang (2001), Indonesian Intergovernmental Transfer In Decentralization Era :The Case Of General Allocation Fund. Dipublikasikan pada International Symposium on Intergovernmental Transfers in Asian Countries : Issues and Practices Asian Tax and Public Policy Program, Hitotsubashi University.

Halim, Abdul (2004), Bunga Rampai Manajemen Keuangan Daerah Edisi Revisi, UPP UMP YKPN, Yogyakarta.

Haryati, Sri (2006), "Perbandingan Kinerja Keuangan Daerah Sebelum Dan Sesudah Kebijakan Otonomi Daerah Kabupaten Sleman Tahun 1998-2000 Dan 2001-2003", skripsi sarjana Fakultas Ekonomi, Universitas Islam Indonesia, Yogyakarta.

Mardiasmo (2002), Otonomi dan Manajemen Keuangan Daerah, Andi, Yogyakarta

Maskhuri (2005), Desentralisasi Fiskal Dalam Perspektif Kemandirian Dan Pemerataan Di Sulawesi Selatan, Thesis (tidak dipublikasikan) Pasca Sarjana Fakultas Ekonomi Universitas Hasanudddin, Makassar.

Nappalos, Scott. 2013. Democratic Centralism in Practice and Idea: A Critical Evaluation. Johannesburg: Zabalaza Books.

Oates, W, 1993, Fiscal Decentralization and Economic Development, National Tax Journal, XLVI. 237-243.

Saragih, Juli Panglima (2003), Desentralisasi Fiskal dan Keuangan Daerah dalam Otonomi, PT Ghalia Indonesia, Jakarta.

Setiarti, L. (2002), "Analisis Kemampuan Keuangan Daerah dalam Pelaksanaan Otonomi Daerah : studi di kabupaten Bantul Yogyakarta", Jurnal Ekonomi Pembangunan, Volume III, No. 2, 141-152.

Sucipto (2003), "Penilaian Kinerja Keuangan", Universitas Sumatra Utara, Medan.

Sumarsono, Hadi (2009. Analisis Kemandirian Otonomi Daerah: Kasus Kota Malang (19992004). JESP Vol. 1 No.1, 2009. Malang

Susanto, Sudono .2001., " Analisa Perimbangan Pembiayaan Fiskal Pemerintah Pusat dan Daerah Studi kasus Kabupaten Banjarnegara ", Skripsi Sarjana Fakultas Ekonomi, Universitas Islam Indonesia, Yogyakarta.

Sidik, Machfud. 2002. Optimalisasi Pajak Daerah dan Retribusi Daerah Dalam Rangka Meningkatkan Kemampuan Keuangan Daerah.

Undang - Undang Otonomi Daerah 2004, Penerbit Absolut.

Vazques,Jorge Martines dan Z.F. Jameson Boex (1997), "Fiscal Capacity: an Overview of concepts and Measurement Issues and Their Applicability in The Russian Federation", Policy Research Centre, School of policy Studies, Georgia State University.

Yani, Ahmad (2002), Hubungan Keuangan Antara Pemerintah Pusat dan Daerah di Indonesia, PT Raja Grafindo Persada, Jakarta.

Zamhuri, M.Y (2008). Modul:Perhitungan Potensi Pajak dan Retribusi Daerah.Lembaga Penelitian Universitas Hasanuddin.

Thayer, Carlyle A. 2002. "Vietnam in 2001: The Ninth Party Congress and After." Asian Survey 42 (1) : 81-89. 